\title{
A comparison of the intraocular pressure response between two different intensities and volumes of resistance training
}

\author{
Comparação de resposta da pressão intraocular frente a duas \\ diferentes intensidades e volumes do treinamento resistido
}

Marcelo Conte ${ }^{1,2}$; Marinho Jorge Scarpi ${ }^{1}$

\begin{abstract}
Purpose: To verify the influence of two different intensities and volumes of resistance training on intraocular pressur. Method: Nineteen athletes boxers (13 male and 6 female; mean age of $22 \pm 3$ years) were randomly assigned to two different resistance exercise sessions: muscular endurance with 3 sets of 15 repetition maximum and muscular hypertrophy with 4 sets of 8 RM. The intraocular pressure was measured with a Perkins tonometer before, during and after the resistance exercise sessions. Data were expressed as mean and standard deviation. A repeated-measures analysis of variance (ANOVA) was used and the Tukey post hoc test for multiple comparisons were applied. Results: A reduction in intraocular pressure during the resistance exercise session was observed. However, the muscular endurance exercise produced a significant reduction in intraocular pressure when compared with muscular hypertrophy. At the end of session, intraocular pressure returned to pre-exercise levels in muscular endurance session and above to pre-exercise levels in hypertrophy session. Conclusion: Resistance exercises influence intraocular pressure values, thus 3 sets of 15 repetitions with $60 \% 1 \mathrm{RM}$ promote better intraocular pressure responses than 3 sets of 8 repetitions with $80 \% 1 \mathrm{RM}$. This finding of the present research can contribute in prescription of resistance exercise to people with glaucoma risk factors.
\end{abstract}

Keywords: Intraocular pressure; Resistance training; Motor activity; Ophthalmology; Physical exercise

\section{RESUMO}

Objetivo: Verificar a influência de duas diferentes intensidades e volumes de treinamento resistido na pressão intraocular . Método: Dezenove boxeadores (13 homens e 6 mulheres; idade média de $22 \pm 3$ anos) foram randomicamente submetidos a duas diferentes sessões de exercícios resistidos: resistência muscular com 3 séries de 15 repetições máximas e hipertrofia muscular com 4 séries de 8RM. A pressão intraocular foi obtida com Tonometro de Perkins antes, durante e após as sessões de exercício resistido. Os dados foram expressos em média e desvio padrão. Foi realizada análise de variância (ANOVA) com medidas repetidas e pós teste de Tukey. Resultados: Foi observada redução da pressão intraocular durante as sessões de treinamento resistido. Contudo, a sessão de exercício para resistência muscular promoveu redução significativa da pressão intraocular comprada a de hipertrofia muscular. Ao final da sessão de resistência muscular a pressão intraocular retornou aos valores prévios ao exercício, por outro lado na sessão de hipertrofia muscular a pressão intraocular após o término dos exercícios apresentou-se acima dos valores iniciais. Conclusão: $O$ treinamento resistido pode influenciar os valores da pressão intraocular, especificamente 3 séries de 15 repetições com $60 \%$ de 1 RM promoveu respostas hipotensivas mais expressivas na pressão intraocular do que 3 séries de 8 repetições com $80 \%$ de 1 RM. Esses achados podem contribuir para prescrição de exercício resistido para pessoas com fatores de risco para o glaucoma.

Descritores: Pressão intraocular; Treinamento resistido; Atividade motora; Oftalmologia; Exercício físico

\footnotetext{
'São Paulo Medical School, Federal University of São Paulo, São Paulo/SP, Brazil.

${ }^{2} J u n d i a i ́$ Physical Education School, Jundiaí/SP, Brazil.

Research Ethics Commission of the Federal University of São Paulo, Project 1527/07
}

The authors declare no conflicts of interest

Received for publication: 22/1/2013 - Accepted for publication: 10/9/2013

Rev Bras Oftalmol. 2014; 73 (1): 23-7 


\section{INTRODUCTION}

$\mathbf{T}$ he association between intraocular pressure (IOP) and exercise has been investigated for many years ${ }^{(1,2)}$, but there are few studies on the association between IOP and resistance training (RT). Most previous studies employed study designs that do not correspond to typical resistance exercise sessions and did not explore variations in RT volume and inten$\operatorname{sity}^{(4,5)}$.

In aerobic exercise, IOP reduction is proportional to exercise intensity but it is not related to volume (the duration of an exercise session $)^{(6)}$. A possible explanation for this phenomenon is autonomic nervous system stimulation induced by physical exercise $^{(7)}$. In general, both in physically active and sedentary individuals IOP declines more sharply during aerobic than anaerobic activities ${ }^{(8)}$. In isokinetic exercise, where resistance depends on the strength and speed of movement, IOP reduction is more significant than in isometric exercise ${ }^{(9)}$.

Specifically with regard to RT, IOP reduction has been observed after the bench press exercise ( 1 set of 8 repetitions with $85 \%$ of one-repetition maximum, or $1 \mathrm{RM})^{(3)}$. IOP reduction was also assessed immediately after the bench press and leg press exercises ( 3 sets of 10 repetitions with $70 \% 1 \mathrm{RM})^{(4)}$. Another study evaluated IOP on 30 male subjects before and after the bench press exercise ( 1 set of four repetitions with $80 \% 1 \mathrm{RM}$ ) in two conditions: apnea and breathing continuously; a significant increase in IOP was found in apnea compared with continuous breathing ${ }^{(5)}$. The authors suggested that increased pressure in the thorax (in apnea) may decrease venous return, impairing the drainage of aqueous humour (AH). Finally, in another study with 145 young individuals of both sexes, there was significant reduction in IOP after a strength test in RE; the increase in plasma lactate caused by this type of effort was a key aspect to explain changes in $\mathrm{IOP}^{(10)}$.

Therefore, the available evidence suggests that low-intensity, high-volume RT can promote greater reductions in IOP than high-intensity, low-volume RT. Two conditions support this hypothesis: lower loads (intensity) with more repetitions (volume) promote increased plasma lactate concentrations, while higher loads with fewer repetitions tend to induce apnea. However, there are few studies investigating and comparing the effects of RT in IOP; therefore, the aim of this study was to determine the influence of two different RT intensities and volumes on IOP.

\section{Methods}

Sample

The study included 19 volunteers (13 men and 6 women) with a mean age of $22 \pm 3$ years. The study was conducted in agreement with the ethical principles of the Declaration of Helsinki proposed by the World Medical Association. The study was approved by the Ethics Committee on Human Research of the Federal University of São Paulo (document 1527/07). The following exclusion criteria were adopted: i) no RT experience; ii) current use of dietary supplements, medications, or other drugs; iii) current or previous use of anabolic androgenic steroids; and iv) any ophthalmic abnormalities identified in the ophthalmic examination conducted before the study. Volunteers were included in the study based on the following criteria: i) boxing athletes affiliated to the Sorocaba Boxing League with at least three months of training; ii) both sexes; iii) age between 18 and 20 years; iv) no injuries; v) no media opacities, i.e., cornea/lens/vitreous opacity, and/or changes in eyeball volume or absence of eyeball.
Box 1

Characteristics of RT sessions

\begin{tabular}{lcc}
\hline \multirow{2}{*}{ Variable } & \multicolumn{2}{c}{ SESSION } \\
\cline { 2 - 3 } & $\begin{array}{c}\text { Muscle } \\
\text { endurance }\end{array}$ & $\begin{array}{c}\text { Muscle } \\
\text { hypertrophy }\end{array}$ \\
\hline Intensity & $60 \% 1 \mathrm{RM}$ & $80 \% 1 \mathrm{RM}$ \\
Repetitions & 15 & 8 \\
Sets & 3 & 3 \\
Time between sets & 30 seconds & 90 seconds \\
Speed of repetitions & Moderate & Moderate \\
\hline
\end{tabular}

$1 \mathrm{RM}=$ one-repetition maximum

\section{Materials and procedures}

All participants underwent previous ophthalmic examination including visual acuity testing (LogMar chart), ocular motility (cover test), ultrasound pachymetry (three measures), and IOP testing (Perkins Tonometer, Clement Clarke H/S). Initial tests found that no subject had changes in visual acuity or ocular motility, and no IOP above $17 \mathrm{mmHg}$ was recorded.

Training and control sessions occurred in a bodybuilding gym in February 2009, always starting at the same time (2 pm). Volunteers were instructed to comply with the following recommendations in the two weeks prior to the experiment: sleeping 7-8 hours per night; abstaining from caffeine, alcohol, drugs, and physical activity; and maintaining a regular diet (four to five balanced meals a day). Before each workout and control session food consumption (three hours before the experiment) and hydration (500 $\mathrm{ml}$ of water two hours before the experiment) were standardised. The volunteers were randomised into two groups for two different RT and control sessions.

The intensity and volume of exercise sessions were based on typical RT programmes ${ }^{(11-13)}$. Exercise sessions were aimed at promoting muscle endurance (higher volume and lower intensity) or muscle hypertrophy (lower volume and higher intensity). Box 1 shows the characteristics of the RT sessions. Exercise sets were identical in the two RT sessions: 1) bench press; 2) incline bench press; 3) pulldown; 4) upright row; 5) deltoid development; 6) shoulder fly; 7) standing barbell curl; 8) pushdown; 9) reverse curl; 10) $45^{\circ}$ leg press; 11) leg curl 12) and seated calf raise. These exercises were selected because they are prescribed in most RT programmes and because they exercise different muscle groups ${ }^{(13)}$.

IOP measurements were made by the same ophthalmologist using a Perkins applanation tonometer at six time points: i) before exercise (PRE): immediately prior to the start of the training session; ii) exercise 1 (E1): during the workout session, immediately after finishing the bench press exercise (5 minutes after the start of the workout); iii) exercise 2 (E2): during the workout session, immediately after finishing the standing barbell curl exercise (35 minutes after the start of the workout); iv) exercise 3 (E3): during the workout session, immediately after finishing the $45^{\circ}$ leg press exercise (50 minutes after the start of the workout); v) recovery 1 (R1): three minutes after finishing the workout (63 minutes after the start of the workout); and vi) recovery 2 (R2): six minutes after finishing the workout (66 minutes after the start of the workout).

IOP was measured with volunteers sitting and focusing on a distant object with the contralateral eye after instillation of one proparacaine eye drop and one fluorescein eye drop.

The control test was performed with the same volunteers, 
Table 1

Comparing IOP values for each RT and control time point in the right eye

\begin{tabular}{lcccccc}
\hline \multirow{2}{*}{ Condition } & \multicolumn{7}{c}{ Time point } \\
\cline { 2 - 7 } & Pre & E1 & E2 & E3 & R1 & R2 \\
\hline Endurance & $11,05 \pm 2,36$ & $8,84 \pm 2,29^{\mathbf{a}}$ & $8,63 \pm 1,97^{\mathbf{a}}$ & $10,05 \pm 2,26^{\mathbf{b}}$ & $10,57 \pm 2,36^{\mathbf{b}}$ & $11,27 \pm 2,86^{\mathbf{b}}$ \\
Hypertrophy & $11,50 \pm 2,12$ & $9,81 \pm 1,60^{\mathbf{a}}$ & $10,75 \pm 1,94$ & $11,66 \pm 1,79^{\mathbf{b}}$ & $12,33 \pm 2,46^{\mathbf{b}}$ & $13,12 \pm 2,7^{\mathbf{a} ; b ; c ; d ; e}$ \\
Control & $11,28 \pm 2,43$ & $11,02 \pm 2,23$ & $10,99 \pm 2,70$ & $11,10 \pm 2,44$ & $11,06 \pm 2,18$ & $11,20 \pm 2,78$ \\
\hline
\end{tabular}

Table 2

Comparing IOP values for each RT and control session in the left eye

\begin{tabular}{|c|c|c|c|c|c|c|}
\hline Condition & \multicolumn{6}{|c|}{ Time point } \\
\hline Endurance & $11,60 \pm 2,29$ & $9,00 \pm 2,35^{\mathbf{a}}$ & $9,15 \pm 1,86^{\mathbf{a}}$ & $9,94 \pm 2,68^{\mathbf{a}}$ & $10,68 \pm 2,34^{\mathbf{b}}$ & $11,94 \pm 3,04^{\mathbf{b}}$ \\
\hline Hypertrophy & $11,87 \pm 2,21$ & $10,56 \pm 1,67^{\mathbf{a}}$ & $10,43 \pm 2,06^{\mathbf{a}}$ & $11,53 \pm 1,95^{\mathrm{c}}$ & $12,46 \pm 2,44^{\mathbf{b}, \mathbf{c}}$ & $13,18 \pm 1,72^{\mathbf{a} ; \mathbf{b} ; \mathbf{c} ; \mathbf{d} ; \mathbf{e}}$ \\
\hline Control & $11,78 \pm 2,52$ & $11,53 \pm 2,19$ & $11,22 \pm 2,35$ & $11,47 \pm 2,78$ & $11,82 \pm 2,39$ & $11,66 \pm 2,40$ \\
\hline
\end{tabular}

${ }^{a}$ Statistically-significant difference compared with PRE ( $\left.\mathrm{p} \leq 0.05\right)$; ${ }^{\mathrm{b}}$ Statistically-significant difference compared with E1 ( $\left.\mathrm{p} \leq 0.05\right)$; ${ }^{\mathrm{c} S t a t i s t i c a l l y-s i g n i f i c a n t}$ difference compared with E2 ( $\mathrm{p} \leq 0.05)$; ${ }^{\mathrm{d}}$ Statistically-significant difference compared with $\mathrm{E} 3(\mathrm{p} \leq 0.05)$; ${ }^{\mathrm{e}}$ Statistically significant difference compared with R1 ( $\leq 0.05)$. Lowercase was used for comparisons between sessions of the same training or control session. $\mathrm{P}$ was used to indicate statistical difference.

who underwent similar repeated IOP measurements (at time intervals identical to those of the exercise sessions) but in a resting state and in the sitting position. The time between the exercise and control sessions was 72 hours.

\section{Statistical Analysis}

Statistical analysis included the Shapiro-Wilk normality test and the homoscedasticity test (Bartlett's test); all variables had normal distribution and homoscedasticity. Data were expressed as means and standard deviations. Analysis of variance with repeated measures (ANOVA) was used (two training and control sessions with five time points). For significant differences the Tukey post-hoc test for multiple comparisons was used. Student's t test was used to determine whether there were significant differences in IOP before the two exercise sessions. A significance level of p d" $5 \%$ was adopted, and the GraphPad Prism ${ }^{\mathrm{TM}}$ software was used. To estimate sample size, IOP values obtained in similar studies were assessed ${ }^{(3,4,5,10,14)}$. Whereas in these studies IOP reduction during exercise sessions ranged from 2.5 to $4 \mathrm{mmHg}$, we estimated that a sample of 15 subjects would have an $80 \%$ statistical power to detect a $4 \mathrm{mmHg}$ reduction in IOP (standard deviation of $4 \mathrm{mmHg}$ ) with a two-tailed alpha $<0.05$.

\section{Results}

Tables 1 and 2 show the comparison of IOP values for each time point in the RT and control sessions in both eyes. In all RT sessions IOP reduction was observed after the first exercise measure (E1). The same result was obtained in the second measure (E2), except in the left eye (LE) in the muscle hypertrophy session. In the latter, IOP increased significantly after E3 and remained high during $\mathrm{R} 1$ and $\mathrm{R} 2$. In the control condition, IOP did not change significantly.

\section{Discussion}

As in previous studies there was a significant reduction in IOP during RT sessions, regardless of the volume or intensity of exercise sessions ${ }^{(3,4,10)}$. However, previous studies assessed IOP only before and after one or two resistance exercises. We assessed IOP before, during and after the completion of two full RT sessions (totalling 12 exercises each) with different intensities and volumes.

During low-intensity, high-volume RT sessions (muscle endurance) IOP decreased significantly after the first exercise (bench press) and remained low after the seventh exercise (standing barbell curl) and the tenth exercise ( $45^{\circ}$ leg press); however, six minutes after completion of the RT session IOP values returned to baseline levels. In the low-volume, high-intensity RT session (muscle hypertrophy), IOP decreased after the bench press exercise but increased after the $45^{\circ}$ leg press exercise and remained higher than baseline levels even after the recovery period (R1 and R2).

Although both types of sessions produced a decrease in IOP after the first exercise, only the muscle endurance session caused it to remain low throughout the RT session; conversely, in the muscle hypertrophy session the IOP was higher than baseline levels even after six minutes of recovery. In classic studies ${ }^{(1,6,15)}$ that assessed the relationship between aerobic exercise and IOP, high-intensity, low-volume exercise produced greater IOP reductions than high-volume, low-intensity exercise. Therefore, it is clear that IOP response to volume and intensity varies depending on the type of exercise (aerobic or resistance). Unfortunately, we found no other studies comparing different volumes and intensities during RT.

Self-regulation mechanisms in the retinal and choroid circulation may explain the influence of exercise intensity on IOP 
reduction during aerobic activities. ${ }^{(16,17)}$ However, this evidence is not adequate to explain IOP reductions associated with RT because, as opposed to aerobic exercise, RT is an intermittent activity with lower cardiac output.

On the other hand, IOP reductions during RT are associated with physiological control of the $\mathrm{AH}$, which depends on four factors: 1) $\mathrm{AH}$ production; 2) resistance to $\mathrm{AH}$ drainage; 3 ) episcleral venous pressure; and 4) uveoscleral and trabecular flow ${ }^{(18)}$. Increased blood acidosis can decrease AH production. Studies have shown that intensities above 30\% 1RM are sufficient to determine the predominance of glycolytic activity in RT with a consequent increase in lactate concentrations $^{(19,20)}$. Other studies have also shown significant elevations of blood lactate (up to $24 \mathrm{mmol}$ ) after training at $80 \%$ $1 \mathrm{RM}^{(21)}$. In this context, the reduction in blood $\mathrm{pH}$ causes fluidelectrolyte imbalance with consequent reduction of $\mathrm{AH}$ production. Lowering the $\mathrm{pH}$ decreases the activity of the sodium $\left(\mathrm{Na}^{+}\right)$pump in the ciliary body to maintain local homeostasis $^{(3)}$. Increased blood lactate with decreased blood $\mathrm{pH}$ is thus one of the main factors explaining changes in IOP caused by exercise ${ }^{(22)}$.

Whereas the drainage of 0.28 microlitres $/ \mathrm{min} / \mathrm{mmHg}$ of $\mathrm{AH}$ is enough to cause a $1 \mathrm{mmHg}$ reduction in IOP, the 3 $\mathrm{mmHg}$ reduction in IOP recorded at E1 after 5 minutes of exercise is compatible with the time required to reduce the production of $\mathrm{AH}$, albeit temporarily, since the $\mathrm{AH}$ is produced in the ciliary body at an average rate of 2 to 3 microlitres per minute ${ }^{(18)}$.

IOP reduction is related not only to reduced $\mathrm{AH}$ production, but also to increased $\mathrm{AH}$ drainage. Increased $\mathrm{AH}$ drainage can be caused by exercise, hypercapnia and consequent hyperventilation, which in turn leads to a reduction in venous pressure and possibly $\mathrm{IOP}^{(23)}$.

A recent review on glaucoma, IOP and ocular blood flow during isometric and dynamic exercise showed that isometric exercise causes acute IOP reduction, but such a reduction is more significant during dynamic exercise. The physiological mechanisms that explain this phenomenon remain unknown and have not been sufficiently studied, but there is a consensus that decreased $\mathrm{pH}$, increased plasma osmolality, and increased blood lactate are the primary factors for IOP reduction due to exercise $^{(24)}$.

In the present study, IOP reduction cannot be explained by the theory of increased osmolality, as this occurs mostly in long-term aerobic exercise performed in hot environments in association with fluid restriction. Exercise sessions in this study were performed indoors in a fresh place, had a maximum duration of one hour, and although the hydration of volunteers was not controlled, they were allowed to drink water at will during RT.

The physiological mechanisms responsible for changes in IOP are not yet fully understood, especially because it is not possible observe AH dynamics simultaneously with muscle contraction. However, there is strong evidence that certain physical activity conditions, when performed regularly over the years, can reduce $\mathrm{IOP}^{(25)}$.

\section{Conclusion}

Resistance training can influence IOP values; specifically, 3 sets of 15 repetitions at $60 \% 1 \mathrm{RM}$ promoted more significant reductions in IOP than 3 sets of 8 repetitions at
$80 \% 1 \mathrm{RM}$. These findings may contribute to the prescription of resistance exercise for persons with risk factors for glaucoma

\section{REFERÊNCIAS}

1. Lempert P, Cooper KH, Culver JF, Tredici TJ. The effect of exercise on intraocular pressure. Am J Ophthalmol.1967;63(6):1673-6.

2. Dane S, Koçer I, Demirel H, Ucok K, Tan U. Effect of acute submaximal exercise on intraocular pressure in athletes and sedentary subjects. Int J Neurosci. 2006;116(10):1223-30.

3. Vieira GM, Penna EP, Marques MB, Bezerra RF. The accute effects of resistance exercise on intraocular pressure. Arq Bras Oftalmol. 2003;66(4):431-5.

4. Chromiak JA, Abadie BR, Braswell RA, Koh YS, Chilek DR. Resis tance training exercises acutely reduce intraocular pressure in physically active men and women. J Strength Cond Res. 2003;17(4):715-20.

5. Vieira GM, Oliveira HB, de Andrade DT, Bottaro M, Ritch R. Intraocular pressure variation during weight lifting. Arch Ophthlamol. 2006;124(9):1251-4. Comment in Arch Ophthalmol. 2008;126(2):2878 ; author reply 288.

6. Kiuchi Y, Mishima HK, Hotehama Y, Furumoto A, Hirota A, Onari K. Exercise intensity determines the magnitude of IOP decrease after running. Jpn J Ophthalmol.1994;38(2):191-5.

7. Güngör K, Beydagi H, Bekir N, Arslan C, Süer C, Erbagci I, et al. The impact of acute dynamic exercise on intraocular pressure: role of the beta 2-adrenergic receptor polymorphism. J Int Med Res. 2002;30(1):26-33.

8. Ozmerdivenli R, Simsek E, Bulut S, Karacabey K, Saygin O. Comparison of the effects of acute and regular exercise on intraocular pressure in Turkish athlete and sedentarians. Int J Neurosci. 2006;116(3):35160.

9. Avunduk AM, Yilmaz B, Sahin N, Kapicioglu Z, Dayanir V.The comparison of intraocular pressure reductions after isometric and isokinetic exercises in normal individuals. Ophthalmologica. 1999;213(5):290-4.

10. Conte M, Scarpi MJ, Rossin RA, Beteli HR, Lopes RG, Marcos HL. Variação da pressão intra-ocular após teste submáximo de força no treinamento resistido. Arq Bras Oftalmol. 2009;72(3):351-4

11. American College of Sports Medicine. American College of Sports Medicine position stand. Progression models in resistance training for healthy adults. Med Sci Sports Exerc. 2009;41(3):687-708. Review.

12. Prestes J, De Lima C, Frollini AB, Donatto FF, Conte M. Comparison of linear and reverse linear periodization effects on maximal strength and body composition. J Strength Cond Res. 2009;23(1):266-74.

13. Kraemer WJ,Adams K, Cafarelli E, Dudley GA, Dooly C,Feigenbaum MS, Fleck SJ, Franklin B, Fry AC, Hoffman JR, Newton RU, Potteiger J, Stone MH, Ratamess NA, Triplett-McBride T; American College of Sports and Medicine. American College of Sports Medicine position stand. Progression models in resistance training for healthy adults. Med Sci Sports Exerc. 2002;34(2):364-80.

14. Qureshi IA. Effects of mild, moderate and severe exercise on intraocular pressure of sedentary subjects. Ann Hum Biol. 1995;22(6):545-53.

15. Qureshi IA, Xi XR, Huang YB, Wu XD. Magnitude of decrease in intraocular pressure depends upon intensity of exercise. Korean J Ophthalmol. 1996;10(2):109-15.

16. Lovasik JV, Kergoat H. Consequences of an increase in the ocular perfusion pressure on the pulsatile ocular blood flow. Optom Vis Sci. 2004;81(9):692-8.

17. Kozobolis VP, Detorakis ET, Konstas AG, Achtaropoulos AK, Diamandides ED. Retrobulbar blood flow and ophthalmic perfusion in maximum dynamic exercise. Clin Experiment Ophthalmol. 2008;36(2):123-9.

18. Shields MB.Textbook of glaucoma. 4a ed. Baltimore: Lippincott Williams \& Wilkins; 1997. 
19. Oliveira JC, Baldissera V, Simões HG, Aguiar AP, Azevedo PH, Poian PA, et al. Identificação do limiar de lactato e limiar glicêmico em exercícios resistidos. Rev Bras Med Esporte. 2006;12(6):333-8.

20. McArdle WD, Katch FI, Katch VL. Fisiologia do exercício: energia, nutrição e desempenho humano. 5a ed. Rio de Janeiro: Guanabara Koogan; 2003.

21. Leveritt M, Abernethy PJ. Acute effects of high-intensity endurance exercise on subsequent resistance activity. J Strength Cond Res.1999;13(1):47-51.

22. Kielar RA, Teraslinna P, Rowe DG, Jackson J. Standardized aerobic and anaerobic exercise: differential effects on intraocular tension, blood pH, and lactate. Invest Ophthalmol Vis Sci. 1975;14(10):782-5.

23. Harris A, Malinovsky VE, Cantor LB, Henderson PA, Martin BJ. Isocapnia blocks exercise-induced reductions in ocular tension. Invest Ophthalmol Vis Sci. 1992;33(7):2229-32.
24. Risner D, Ehrlich R, Kheradiya NS, Siesky B, McCranor L, Harris A. Effects of exercise on intraocular pressure and ocular blood flow: a review. J Glaucoma. 2009;18(6):429-36.

25. Williams PT. Relationship of incident glaucoma versus physical activity and fitness in male runners. Med Sci Sports Exerc. 2009;41(8):1566-72.

\section{Corresponding author:}

\section{Marcelo Conte}

Avenida 14 de Dezembro, no 2115 - Apto 404 / Bloco 04

CEP 13206-105 - Jundiaí - São Paulo - Brazil

Tel. +55116263 3228 Fax. +551145217955

E-mail: contemarcelo@bol.com.br 